\title{
ANALYTICAL STUDY AND TREATMENTS OF THE DECAYED MURAL PAINTINGS AT ATHRIBIS IN SHEIKH HAMAD TEMPLE, SOHAG GOVERNORATE, EGYPT
}

\author{
Ezz A. Orabi ${ }^{1}$ and Ahmed Abu Elyameen Ahmed ${ }^{2}$ \\ ${ }^{1}$ Faculty of Archaeology, Aswan University \\ ezz arabi@yahoo.com \\ ${ }^{2}$ Ministry of Antiquities and Tourism \\ ahmedaboyamin2222@gmail.com
}

\begin{abstract}
This article focuses on the identification of the building materials used at Athribis temple Sohag and their most common degradation factors, and then assessing the most appropriate consolidants for the decayed wall paintings at the temple. The building materials were studied through XRD, SEM-EDX, FTIR spectroscopy and light optical microscope to identify chemical decompositions and physical failures. Soluble salts were detected in the building materials. White pigment is calcium carbonate, yellow pigment goethite, red pigment hematite, blue pigment Egyptian blue, green pigment Egyptian green, the paint medium is animal glue. Conservation treatments were achieved using Ethanol + PLM.I for injecting detached plasters, Sturgeon glue $1.5 \%$ as a filler for cracks, Syton x30 for pre-consolidation, EDTA poultices for cleaning, EDTA for salt extraction, Cidal 50 L50 as a biocide and Klucel $\mathrm{G}$ as a final consolidant.
\end{abstract}

KEYWORDS

Attrips temple; Wall paintings; Pigments; Organic medium; Salts; Consolidation; Cleaning.

\section{INTRODUCTION}

Athribis is an old Egyptian city located on the west bank of the river Nile, that belongeds to the ninth district of Upper Egypt "Akhmim", located about $8 \mathrm{~km}$ from the southwest of Sohag city. The origins of the term Athribis goes back to ancient Egyptian language (Hwt rpyt - the headquarter repit) the goddess" Repit" the female

${ }^{1}$ - Kuhlman K., et.al, Recent Archaeological Exploration, p.143. 
hippopotamus, who was mentioned in many texts discovered on the site especially in the temple of Ptolemy XII (Olitus the piper), then became the Greek "Atrips" ${ }^{2}$, and in Coptic it was known through several names, including "Atrip - Adripp - Atripe e $^{3 "}$

The development of the temple of Athribis started during the reign of Atrips temple dates back to the period of Ptolemy XII (about $80-50$ BC) $)^{4}$. Some additions were made by the Roman Emperors Teripios and Claudios, the temple was finished during the ruling of Hadrian (117-138A.D.). According to the Excavations results, this temple is the only Ptolemaic temple built in limestone in Upper Egypt. The temple extends from the southeast to the northwest with a length of $78 \mathrm{~m}$ and a width of nearly $45 \mathrm{~m}$, it is surrounded by a huge wall of mudbricks. The temple was dedicated to the Trinity of the goddess "Repit", her divine husband "Min"and the child "Kolanthis" remains of the Temple was conducted. The Egyptian-German expedition, which has been working (discovery, Documentation and Registration) in the temple since 2003, has discovered a large part of the Atrips temple (Figure 1), which retains many beautiful inscriptions ${ }^{7}$. Many parts of the temple were lost as it was use as a quarry for many ancient buildings

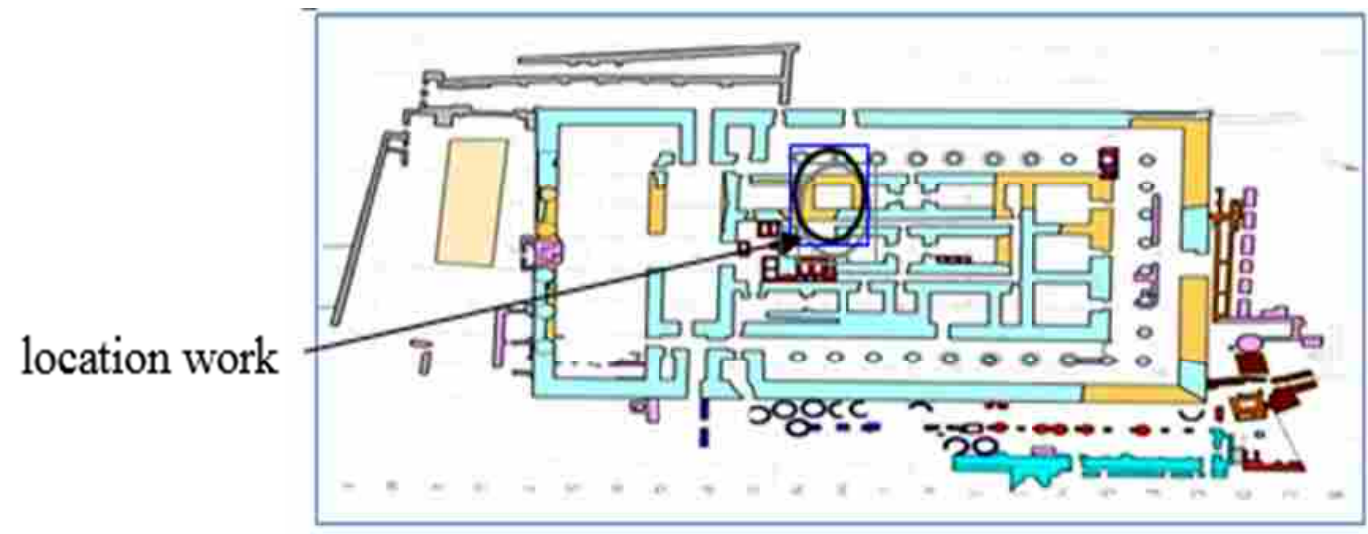

Fig. (1) a general plan of Athribis temple shows location work

Indeed, many of its stone blocks were used in constructing the nearby White monastery in the $5^{\text {th }}$ century $\mathrm{AD}^{8}$. The villagers of the modern (Athribis - Sheikh Hamad) used some of the temple's stones as bases for thier buildings and to erect dams reducing the flood risks ${ }^{9}$. A part of the temple was also used as a barn by the villagers for assembling animals during floods ${ }^{10}$. This has been demonstrated by the various missions' excavations, through studying the sediments seen in the drilled layers. Despite this, the temple walls contain dozens of scenes and traditional texts, commonly seen in Greek and Roman eras' temples ${ }^{11}$, In addition to being recorded,

2 - Nour Eldin A., the ancient archeological sites, p. 139.

3 - Habib R., The Monastery Monasticism, p.177.

4 - Nashi I., The History of Egypt, p. 265.

5 - Mansour N., Akhmim the capital of the ninth region, p 264.

6 - Omran A., A scientific study for the restoration and Conservation, p. 30.

7 - German Mission: Atrips Temple Project.

8 - Meiemardus O., et al., Ancient Egypt, P.294.

9 - Zaki S., Archaeological finds from the excavations, p. 155.

10 - Ibid, p. 6.

11 - Nour Eldin A., The location and museums of the Egyptian monuments, p, 161.

- 239 - Analytical study and treatments of the decayed mural paintings at Athribis 
these should be preserved. This All of these are the reasons prompted the researcher to select this temple for study.

\section{MATERIALS AND METHODS}

\subsection{Investigated materials}

The Limestone, mortars, plasters and pigments from Athribis temple were sampled and prepared for laboratory investigations and analyses which helped to determine their physical structure and chemical composition.

\subsection{Methods}

2.2.1 A stereo microscope type Stemi dr 1663 Zeiss was used.

2.2.2 X-ray diffraction (XRD) analysis was performed using a Philips Model PW 1710 control unit Anode material CU 40 K.V, 30 M.A, Optics: Automatic divergence slit Beta filtering using graphite monochromator, error $=0.16 \%$.

\subsubsection{SEM study was performed using SEM study was performed using JEOL JSM}

5400 LV EDX Link ISIS-Oxford "high vacuum".

2.2.4 FTIR analysis was performed using Nicolet 6700 FT-IR Spectrometer from Thermo Scientific.

\section{RESULTS}

\subsection{Light optical microscope results:}

Most of the pigments were applied directly on the limestone surface after adding a thin layer of whitewash, the latter containing quartz particles in a small amount. All pigments were fine grounded and pulverised as they have a high covering power, homogeneity and interference with the whitewash layer is also observed (Figure 3 to Figure 7,x 50)

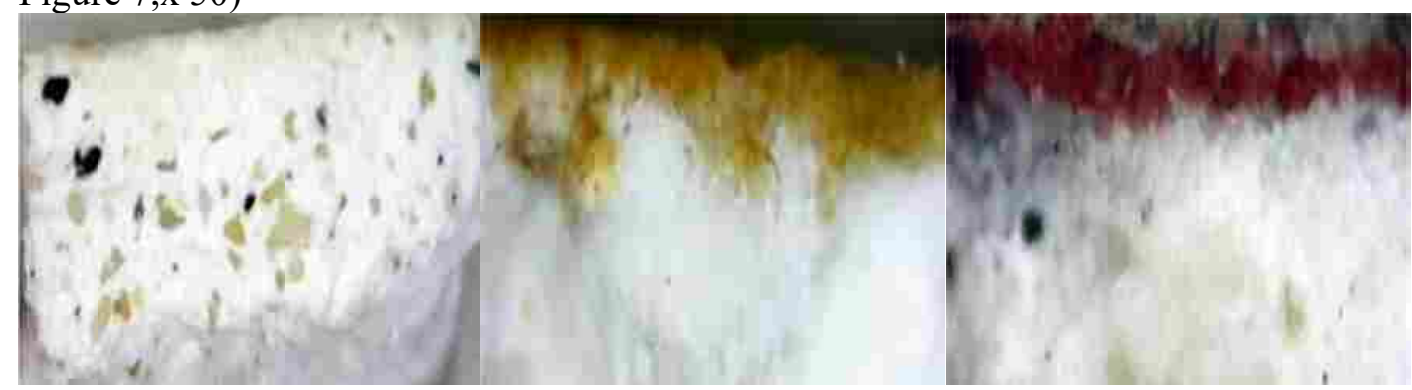

Fig. 2: Thin layer applied to the white pigment from Athribis temple.

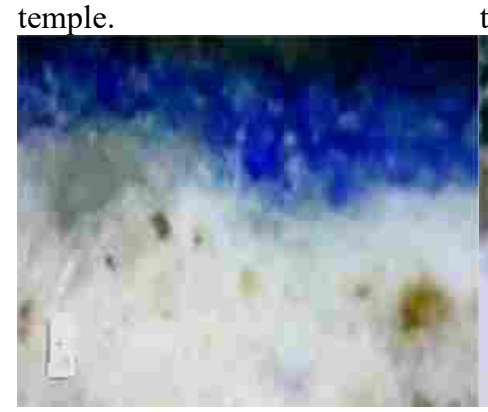

Fig. 5: Thin layer applied of the blue pigment from Athribis temple.
Fig. 3: Thin layer applied of the yellow pigment from Athribis temple.

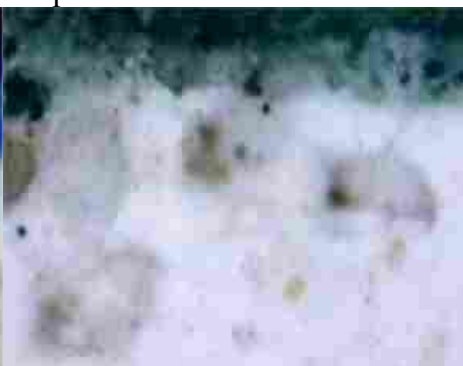

Fig. 6: Thin layer applied of the green pigment from Athribis temple.
Fig. 4: Thin layer applied of the red pigment from Athribis temple.

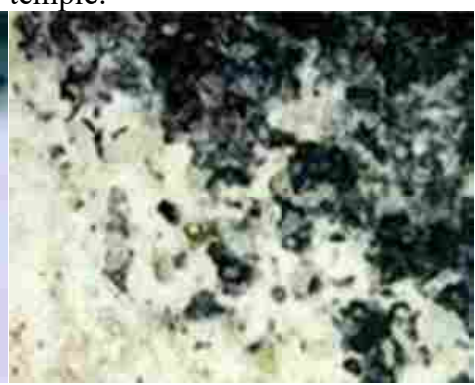

Fig. 7: Thin layer applied of the black pigment from Athribis temple. 


\subsection{XRD results:}

According to XRD analyses, the first sample is a hard limestone as it is a pure calcite $100 \%\left(\mathrm{CaCO}_{3}\right)$ (Figure 8). The second sample white pigment is a calcium carbonate pigment made of $84.8 \%$ calcite $\left(\mathrm{CaCO}_{3}\right)$ and $15.2 \%$ quartz $\left(\mathrm{SiO}_{2}\right)$ (Figure 9). The yellow pigmented plaster sample contains $73.2 \% \mathrm{CaCO}_{3}, 13.9 \%$ goethite $\mathrm{FeO}(\mathrm{OH})$ and $12.9 \%$ hematite $\left(\mathrm{Fe}_{2} \mathrm{O}_{3}\right)$ (Figure10). The red pigmented sample contains $79.5 \%$ gypsum $\left(\mathrm{CaSO}_{4} \cdot 2 \mathrm{H}_{2} \mathrm{O}\right), 14.5 \%$ hematite $\left(\mathrm{Fe}_{2} \mathrm{O}_{3}\right)$ and $6 \%$ halite $(\mathrm{NaCl})$ (Figure 11). The blue pigmented sample is a pure Egyptian blue as it is composed of $100 \%$ cuprorivaite $\mathrm{CaCu} . \mathrm{Si}_{4} \mathrm{O}_{10}$ (Figure 12). The green pigmented plaster sample contains $75.7 \%$ of Egyptian green (Wollastonite $\mathrm{CaCu} . \mathrm{Si}_{3} \mathrm{O}_{9}$ ) complemented with $24.3 \%$ of calcium carbonate $\left(\mathrm{CaCO}_{3}\right)$ (Figure 13).

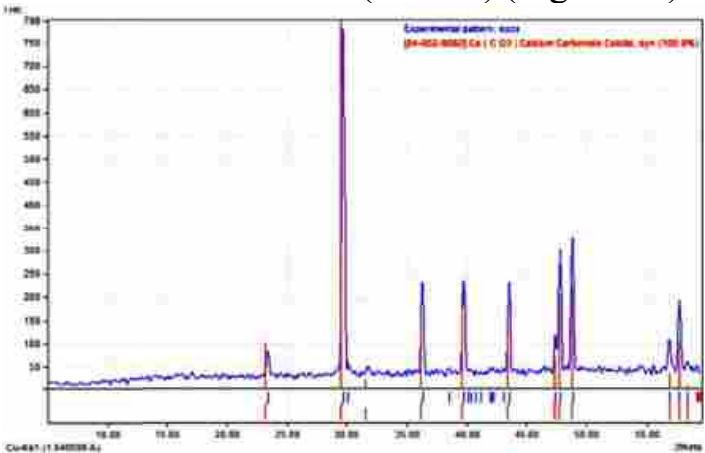

Fig. 8 XRD pattern of the lime stone sample from Athribis temple.

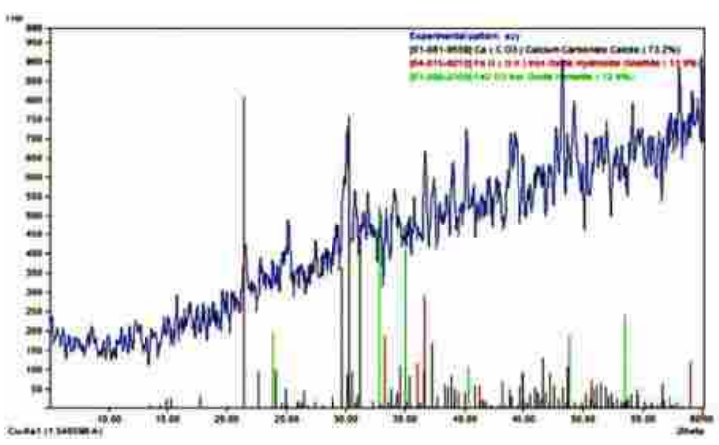

Fig.10 .XRD pattern of the yellow pigment sample from Athribis temple.

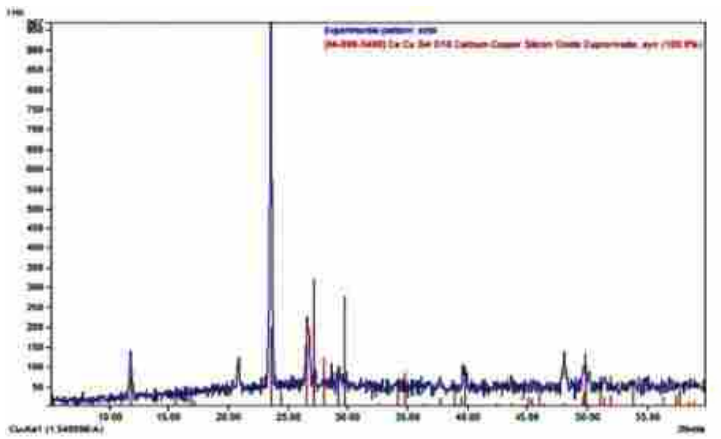

Fig. 12 XRD pattern of the blue pigment sample from Athribis temple.

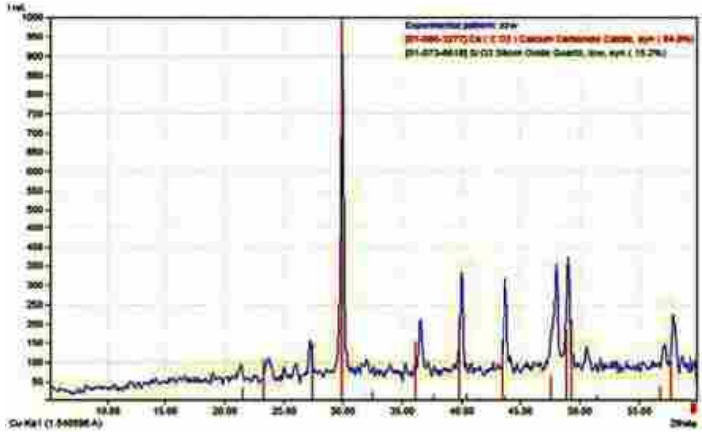

Fig. 9 XRD pattern of the white pigment sample from Athribis temple.

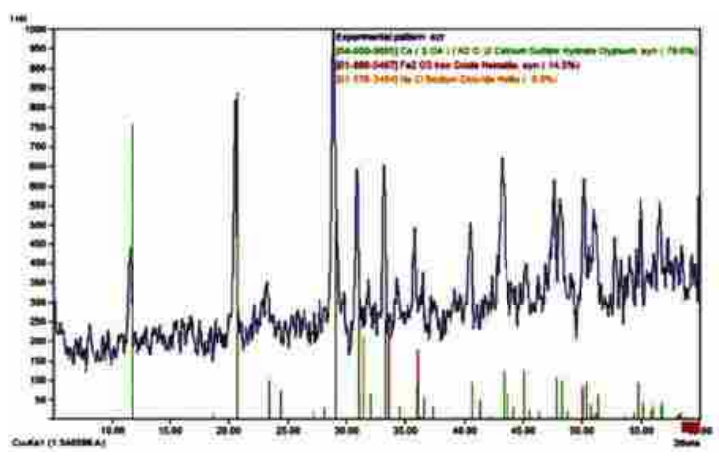

Fig. 11 XRD pattern of the red pigment sample from Athribis temple.

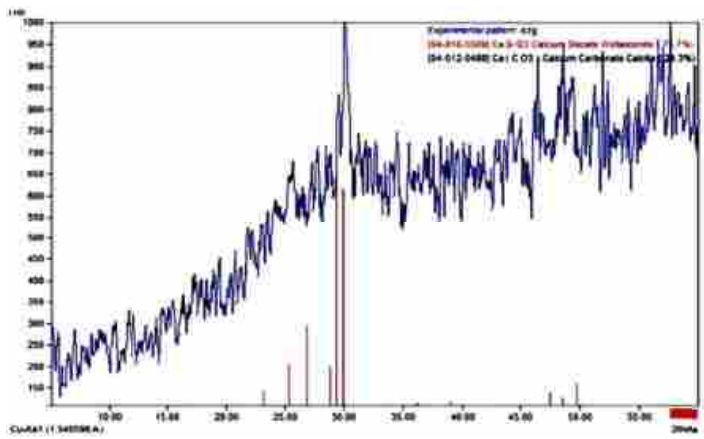

Fig. 13 XRD pattern of the green pigment sample from Athribis temple.

- 241 - Analytical study and treatments of the decayed mural paintings at Athribis 


\subsection{SEM-EDX results:}

Building materials of the temple were studied through SEM-EDX to emphasize the results of the XRD analyses, samples were first investigated and then analysed. The first sample shows that the limestone is suffering from different weathering factors as halite crystals are of different sizes. While the binder is lost in some parts, the EDX analysis shows that the sample is made of $80 \%$ calcium with quartz which may indicate that sand stuck to the stone gaps due to weathering and some traces (Figure 14). The white pigmented plaster sample shows severe deterioration including gaps, cracks, plant fossils and salts. This sample contains some wooden or plant fibers which may be due to the artist's brush (Figure15). EDX analyses show that, the sample contains $72 \%$ calcium, $26 \%$ Sulphur, a small ratio of quartz and some iron traces (Figure 16). The yellow pigmented plaster sample shows gaps and salt crystals between and above pigment particles, EDX analyses show that the sample contains $62 \%$ calcium, $20 \%$ iron and $18 \%$ chlorine (Figure 17 ). According to SEM, the red pigmented plaster sample shows the effect of dissolved salts in the groundwater, mainly gypsum and halite. The EDX shows that the major components are calcium and sulphur, followed by chlorine, a minor amount of iron was also detected. These results are exactly the same as those of the XRD analyses (Figure17). The blue pigmented plaster sample shows under SEM many blisters on the pigment surface, while the EDX proved that the sample is composed of $\mathrm{Ca}, \mathrm{Cu}$, and $\mathrm{Si}$ as major components (Egyptian blue - cuprorivaite) with minor amounts of $\mathrm{Na}$ and $\mathrm{Cl}$ (Figure 18). According to the SEM results, the green pigmented plaster sample suffered from a loss of cohesion between pigment particles, the sample shows also gaps and salt crystals upon its surface, EDX analyses proved that the sample contains $\mathrm{Ca}, \mathrm{Cu}$ and $\mathrm{Si}$ as major components also (Egyptian green - wollastonite), Sulphur was also detected in a significant amount (Figure 19).

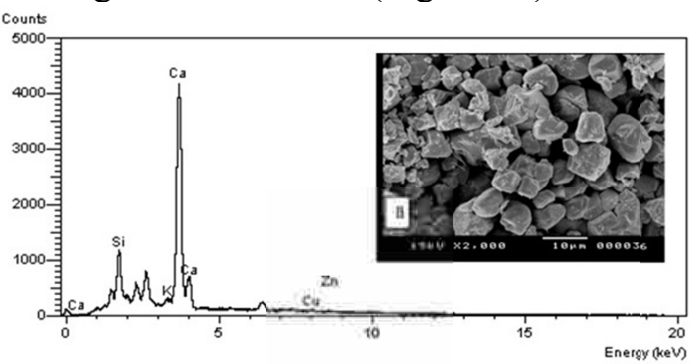

Fig. 14: SEM spectrum and SEM micrograph (2000x) of the limestone sample from Athribis temple.

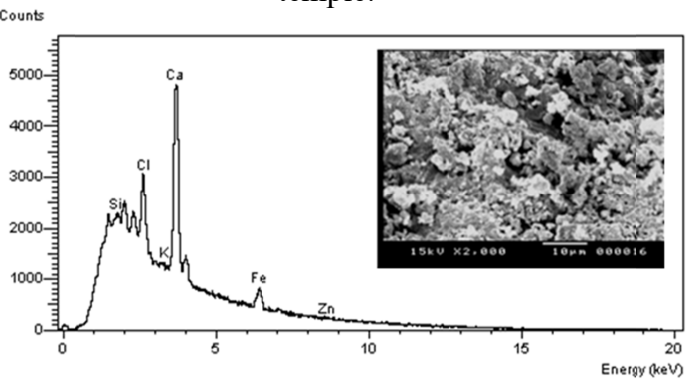

Fig. 16: SEM spectrum and SEM micrograph (2000x) of the yellow pigment sample from Athribis temple.

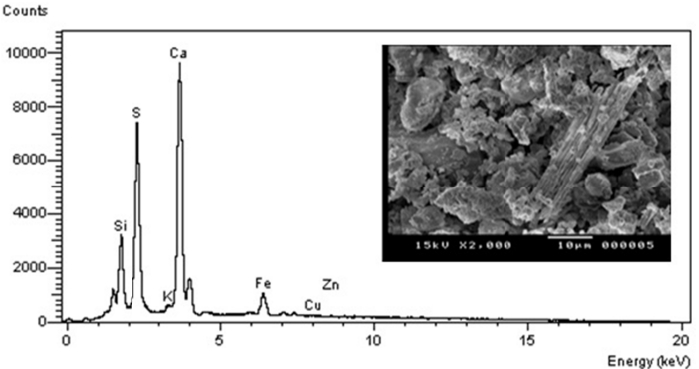

Fig.15: SEM spectrum and SEM micrograph (2000x) of the white pigment sample from Athribis temple.

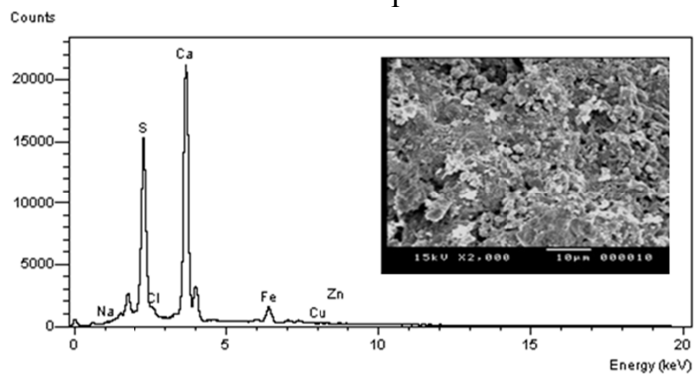

Fig. 17: SEM spectrum and SEM micrograph $(2000 x)$ of the red pigment sample from Athribis temple. 


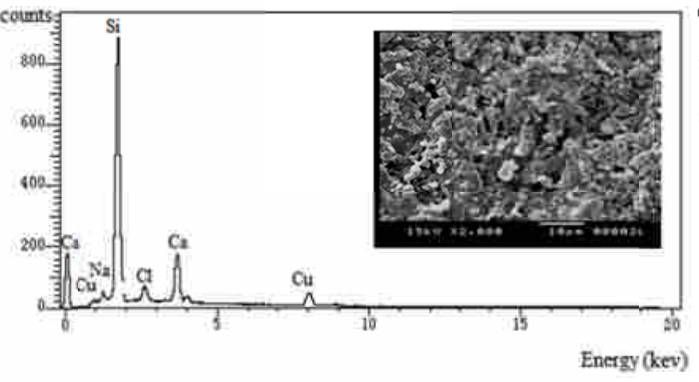

Fig. 18: SEM spectrum and SEM micrograph (2000x) of the blue pigment sample from Athribis temple.

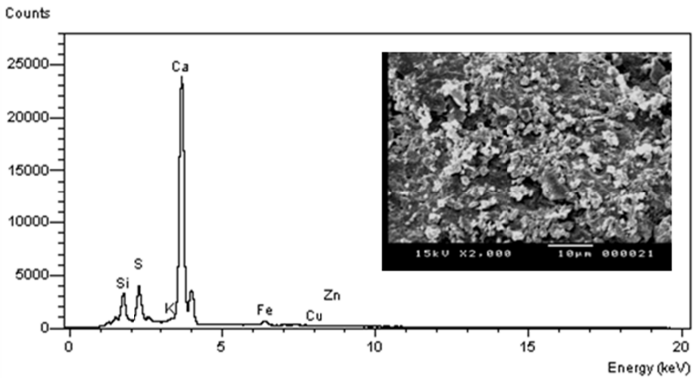

Fig. 19: SEM spectrum and SEM micrograph (2000x) of the blue pigment sample from Athribis temple.

\section{b. FTIR results:}

One paint media sample from mural paintings of the Athribis temple were analysed by mean of FTIR. The results show that the paint medium is animal glue (Figure 20, 21).
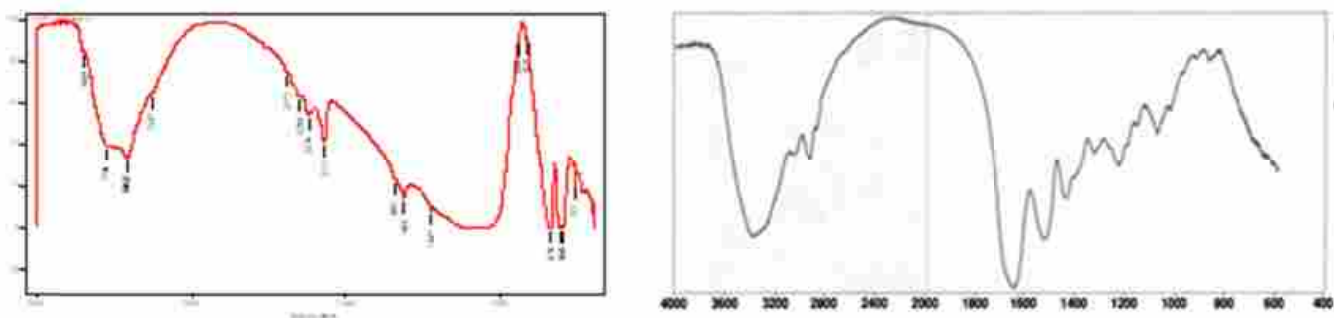

Fig. 20: FTIR spectrum paint medium sample clearly is animal glue. Fig. (21) Standard sample (after Derrick, Stulik and Landry ${ }^{12}$ )

Table (1) shows the wavelength and function groups of Archaeological paint medium sample and animal glue Standard sample.

\begin{tabular}{|c|c|c|c|}
\hline \multicolumn{2}{|c|}{ Archaeological paint medium sample } & \multicolumn{2}{|c|}{ animal glue Standard sample } \\
\hline wavelength & function groups & Wavelength & function groups \\
\hline $\begin{array}{c}3411 \mathrm{~cm}^{-1}-3246 \\
\mathrm{~cm}^{-1}\end{array}$ & $\begin{array}{l}\text { N-H stretching } \\
\text { band }\end{array}$ & $3400-3200 \mathrm{~cm}^{-1}$ & $\mathrm{~N}-\mathrm{H}$ stretching band \\
\hline $\begin{array}{c}3020 \mathrm{~cm}^{-1}-2919 \\
\mathrm{~cm}^{-1}\end{array}$ & $\begin{array}{l}\mathrm{C}-\mathrm{H} \text { stretching } \\
\text { bands }\end{array}$ & $3100-2800 \mathrm{~cm}^{-1}$ & C-H stretching bands \\
\hline $1683 \mathrm{~cm}^{-1}$ & $\begin{array}{c}\mathrm{C}=\mathrm{O} \text { stretching } \\
\text { band }\end{array}$ & $1660-1600 \mathrm{~cm}^{-1}$ & $\mathrm{C}=\mathrm{O}$ stretching band \\
\hline $\begin{array}{c}1623 \mathrm{~cm}^{-1}-1520 \\
\mathrm{~cm}^{-1}\end{array}$ & $\begin{array}{l}\text { C-N-H bending } \\
\text { band }\end{array}$ & $1565-1500 \mathrm{~cm}^{-1}$ & $\mathrm{C}-\mathrm{N}-\mathrm{H}$ bending band \\
\hline $1446 \mathrm{~cm}^{-1}$ & $\mathrm{C}-\mathrm{H}$ bending band & $1480-1300 \mathrm{~cm}^{-1}$ & $\mathrm{C}-\mathrm{H}$ bending band \\
\hline $\begin{array}{c}876 \mathrm{~cm}^{-1}-680 \\
\mathrm{~cm}^{-1}\end{array}$ & $\mathrm{~N}-\mathrm{H}$ group & & \\
\hline
\end{tabular}

12 - Derrick M. R, Stulik D.and Landry J. M., Infrared Spectroscopy, p.181.

- 243 - Analytical study and treatments of the decayed mural paintings at Athribis 


\section{DISCUSSION}

Based on the visual investigation, much deterioration is visible at Athribis temple, such as fragility and detachment of pictorial layers, due to salt crystals, wind erosion, and biological infections. Through an optical microscope, one sees that the pigment layer is homogeneous although salt effloresces. The yellow pigment was applied upon a red pigment layer, this superposition may have been done to increase the covering of the pigment or to give the effect of gilding. SEM investigation showed that the pigment particles lost their correlation as salt crystals grew among them. Moreover, some particles are loosening and falling due to the fragility and detachment of the pictorial layer. According to XRD analyses, the support of the paint is a fine pure hard limestone, a rare instance in Upper Egypt, due to the geological profile of Egypt. Limestone tended to be the support of choice in the north, while sandstone was in the south. Grounded limestone was also the source of the white pigment at the Athribis temple. The presence of sand refers to the painting ground mortars which consisted primarily of gypsum, lime and sand. This portion had been an integral part of masonry structures for thousands of years ${ }^{13}$. Although the temple belongs to the Greek era in Egypt, the same pigment pallet has been in use of the ancient Egyptian style of achieving tempera wall paintings, yellow pigment is still goethite, and the red is hematite, both used in Egyptian murals for millennia. Blue is Egyptian blue, which had been made and use since the fourth dynasty ${ }^{14}$ till the Greco-Roman period ${ }^{15}$. The Egyptian green has the same value than the Egyptian blue, but it started to be use later. EDX has assured the previous results. The FTIR analysis of the organic media proved that the artist used animal glue. This strong binding material was used as a color mediator connecting the color beads together and sticking to the dry painting ground layer in mural paintings since ages ${ }^{16}$.

\section{Treatment and conservation:}

\section{a. Pre-Consolidation:}

The temple's mural paintings are in a bad condition. Its pre-consolidation process is fundamental. The stability of the fragile separated parts must be enhanced before initiating restoration processes. The physicochemical similarity between the treated material and it's consolidated is an important aspect in the consolidation process ${ }^{17}$. Syton $\times 30{ }^{18}$ (Ethyl Silicate protect against corrosion especially underground and industrial atmosphere ${ }^{19}$, Table 2), it used dissolved in water $4 \%$ to re attach the detached pigment layers (Figure 22,23,24,25), table 2. Cracks were injected and

13 - Moussa A., 2018, Nano Treatment of Decayed Cement-Lime Motars p.75.

14 - Lucas A., Materials and industries pp:560-561.

15 - Orabi E., Study and conservation of pigments deterioration, p. 67.

16 - Orabi E., Mural Painting Technology, p. 55.

17 - Victoria E., García V., Antonio J., Tenza A., Afonso M. and Marcos L., Calcium hydroxide nanoparticles, p.1.

18 - Langston L., Conservators of Wall Paintings, p.8.

19 - Parashar G., Srivastava D. and Krumar P., Progress in Organic Coatings,Ethyl silicate binders p. 1. 
strengthened with Sturgeon glue $1.5 \%$. (treated with heating process under $75^{\circ} \mathrm{C}$ ) ${ }^{20}$ (figure 26). This transparent glue does not cause any change in the surface and has excellent adhesive properties, it is also flexible and workable. Japanese paper immerged in Syton30 and dissolved water (10\%) has been used as a fixative for the fragile pigment particles. Klucel G (hydroxypropyl cellulose) dissolved in Ethanol 5\% has also been also used for the same purpose ${ }^{21,22}$.

\section{b. Biological Control: -}

The places of insect's infections have been sterilized by using Ethoxy Carbon di Methyl Phosphor Rothioate known commercially as (Cidal 50 L 50). It has a longlasting phosphoric component that is easy to be applied and excellent safety profile ${ }^{23}$. Methyl bromide was also used in cleaning the biological spots ${ }^{24}$.

\section{c. Cleaning: -}

Mechanical cleaning has been done by brushes of different size, by metallic spatulas sometimes, by scalpels, and by air blower to clear the surface accumulation and to remove dust and sand from the mural painting (Figure 27). EDITA poultice (Tetra Sodium Salt Ethylene Diamine Tetra Acetic Acid) was used conjointly for this purpose (Figure 28, 29, 30), in order to overcome different spots and calcifications $^{25,26,27,28,29}$. Micro emulsions are also used as they are transparent and stable materials ${ }^{30 .}$

\section{d. Salt's extraction: -}

Poultices of distilled water were used to remove the halite salts, in addition to cotton poultices filled with EDTA solution. This enabled the extraction of insoluble salts such as carbonate and sulphate ${ }^{31}$.

\section{a. Completion}

A grout consisting of (sand + matt lime + limestone powder size 250 microns concentrations 2: 1: 1) was applied to fill the gaps, while a mortar of (Ethanol) and

\footnotetext{
${ }^{20-}$ Eriksen A. M., Kristensen H. V. and Boellingtoft p., Bo Botfeldt K. and Rasmussen, Identification of Animal Adhesives, p.369.

${ }^{21}$ - Dan L.,et al, The effect of adding PDMS-OH and Silica nano particles on Sol-gel ,p.368.

22 - Brus, J., and Kotlik, P., Consolidation of Stone, PP: 109-110.

23 - Kovacs R., Gesztelyi R., Berenyi R., Doman M., Kardos G., Juha'sz B. and Majoros L., Killing rates exerted by caspofungin in $50 \%$ serum, p. 186.

${ }^{24}$ - Valentin, N., Libstrom, M., and presser, F., Microbal Control by low oxgen, p. 222.

25 - De Guichen, G., : Object Interred , p . 22 .

26 - Moncreiff, A., and Weaver, G., Cleaning in Science for Conservators, pp. 13-21.

27 - Mora et al, Conservation of Wall painting,p.289.

28 - Torraca,G., Solubility and Solvents for Conservation,p.4.

29 - E. De Witte, M. Dupas, Cleaning poultices based on EDTApp:1023-1031.

$30-$ R. Giorgi and E. Carretti, Cleaning: Applications and Case Studies, pp.236-237.

31 - Ashurst, J. and Ashurst, N., Practical Building Conseruation , p. 77 .
}

\footnotetext{
- 245 - Analytical study and treatments of the decayed mural paintings at Athribis
} 
(PLM.I) powder was prepared. This mortar was injected in fine cracks and used to reattach of the plaster layer.

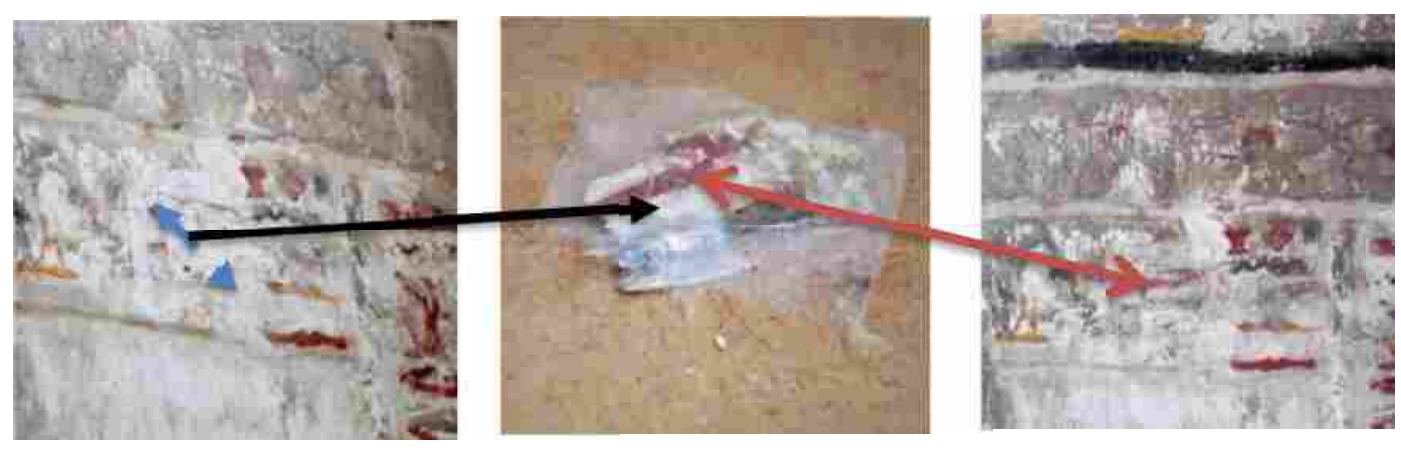

Fig. 22 Detachment part in Fig. 23 The Detachment Fig. 24 Replace the the mural painting part on Japanese Paper

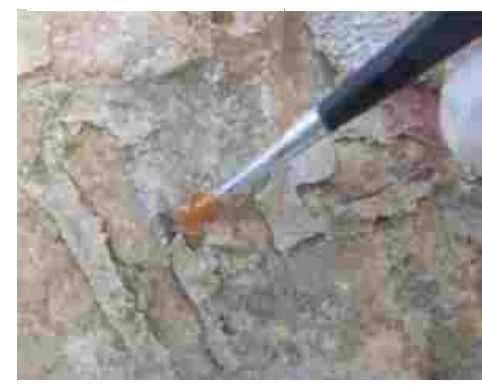

Fig.25 Re attaching the detached pigment layers.

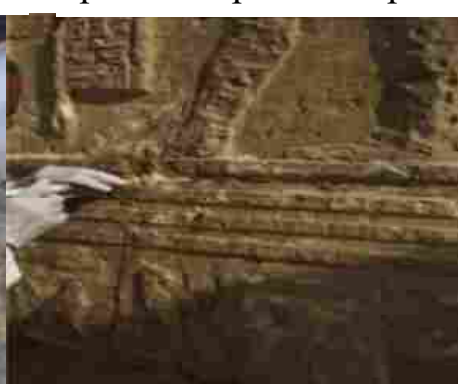

Fig.26 Cracks injected and strengthened with Sturgeon glue separated part in its place

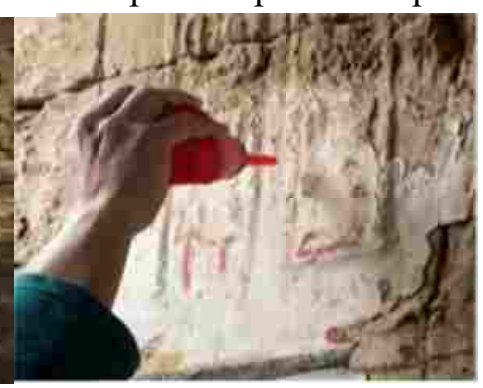

Fig.27 Air blower to remove dust and sand from the mural painting

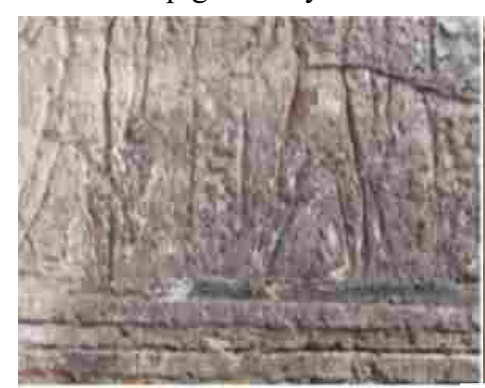

Fig.28 Scene before applying the poultice.

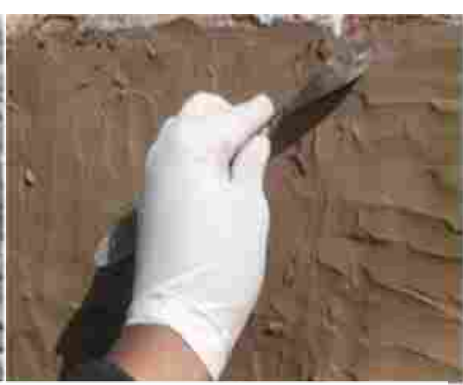

Fig. 29 Scene during the application.

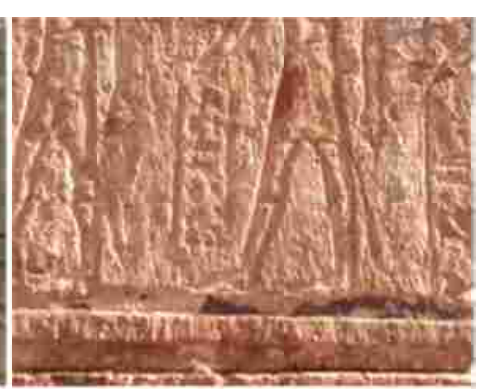

Fig. 30 Scene after cleaning.

\section{CONCLUSIONS}

The mural paintings in Athribis temple were done on a of limestone base that was coated with a whitewash, the ground oxides colors were then applied using the Tempra technique. The analyses showed that the white pigment is calcium carbonate, the yellow pigment goethite, the red pigment hematite, the blue pigment Egyptian blue while the green pigment is Egyptian green. The paint medium is animal glue. The research has pointed out that Athribis temple is suffering many failures such as salts found on the surface of inscriptions and detected in most building materials. There were also cracks in addition to weakness and separating of some colored inscriptions in the form of peeling some insect damaged the appearance also. The research team achieved thorough restoration to enhance the durability of the temple, and to improve the service life of decayed building materials at the temple. 


\section{Appendix 1 Materials treatment:}

Table (2) Additional appendix of the materials treatment.

\begin{tabular}{|c|c|c|c|c|}
\hline No & $\begin{array}{l}\text { commercial } \\
\text { name }\end{array}$ & $\begin{array}{l}\text { scientific } \\
\text { name }\end{array}$ & Company & Properties \\
\hline 1 & $\begin{array}{l}\text { Kalx } \\
\text { kP1060 }\end{array}$ & $\begin{array}{l}\text { Plaster lime } \\
\text { Mortar } \\
\text { injection } \\
\text { (PLMI) }\end{array}$ & Steadfast & $\begin{array}{l}\text { high quality slaked lime injected in } \\
\text { cracks and voids, lime grains size } \\
\text { between 1-2.5 Microns }\end{array}$ \\
\hline 2 & Klucel G & $\begin{array}{l}\text { hydroxypropyl } \\
\text { cellulose }\end{array}$ & $\begin{array}{l}\text { GMW (Geräte } \\
\text { Material } \\
\text { Werkzeug } \\
\text { Germany) }\end{array}$ & $\begin{array}{l}\text { Soluble in water and polar solvents. } \\
\text { Used in low concentrations and in } \\
\text { higher concentrations as an adhesive }\end{array}$ \\
\hline 3 & $\begin{array}{l}\text { Sturgeon } \\
\text { glue }\end{array}$ & $\begin{array}{l}\text { manufacturing } \\
\text { of animal } \\
\text { glue }\end{array}$ & $\begin{array}{l}\text { TALAS } \\
\text { Brooklyn, } \\
\text { New York }\end{array}$ & $\begin{array}{l}\text { Treated with heating process under } \\
75^{\circ} \mathrm{C}\end{array}$ \\
\hline 4 & Sytonx30 & ethyl silicate & $\begin{array}{l}\text { Kremer } \\
\text { Pigmente } \\
\text { GmbH \& Co. } \\
\text { KG } \\
\text { (Germany) }\end{array}$ & $\begin{array}{l}\text { An aqueous silica acid dispersion, } \\
30 \% \text { concentration of silica and a } \\
\text { specific weight of } 1200 \mathrm{~g} / 1\end{array}$ \\
\hline 5 & $\begin{array}{l}\text { Cidal } 50 \mathrm{~L} \\
\mathbf{5 0}\end{array}$ & $\begin{array}{l}\text { Ethoxy } \\
\text { Carbon di } \\
\text { Methyl } \\
\text { Phosphor } \\
\text { Rothioate } \\
\end{array}$ & $\begin{array}{l}\text { States of } \\
\text { America. } \\
\text { Patent and } \\
\text { Trademark } \\
\text { Office }\end{array}$ & $\begin{array}{l}\text { strong in effect, easy to apply, } \\
\text { effective for long periods and } \\
\text { excellent safety profile }\end{array}$ \\
\hline 6 & EDITA & $\begin{array}{l}\text { Tetra Sodium } \\
\text { Salt Ethylene } \\
\text { Diamine Tetra } \\
\text { Acetic Acid }\end{array}$ & & $\begin{array}{l}\text { Its reaction is shallow and does not } \\
\text { penetrate the pores of the murals, } \\
\text { highly capable of dissolving various } \\
\text { materials and planktons and Easily } \\
\text { removed }\end{array}$ \\
\hline
\end{tabular}

\footnotetext{
- 247 - Analytical study and treatments of the decayed mural paintings at Athribis
} 


\section{REFERENCES}

1. Abdel-Aty (Yaser), "Proposals for seismic retrofitting of timber roofs to enhance their inplane stiffness and diaphragm action at historical masonry buildings in Cairo", Journal of Cultural Heritage, Vol. 32, (2018) 73-83 (http://doi.org/10.1016/j.culher.2018.02.005).

2. Abdel-Aty (Yaser), "Roles of timber tie-rods to reduce seismic vulnerability of historical buildings in Egypt", Proceedings of the Institution of Civil Engineers - Structures and Buildings (2019) (In-press: https://doi.org/10.1680/jstbu.19.00091).

3. Abdel-Aty (Yaser), Study the role of timber roofs in the structural stability of arcades in historical mosques and the suitable restoration techniques, with application on one of the mosques in Cairo, the First International Conference for Urban Heritage in the Islamic Countries (UHIC), 23-28 May 2010, Riyadh, Kingdom of Saudi Arabia (Pub. Saudi Commission for Tourism \& Antiquities, 2010) Ar159, on CD.

4. Abdel-Samad (Wael), "Study on the effect of iron rust on properties of antique wood with the application of conservation and treatment on chosen objects", Master thesis, Cairo University, Faculty of Archaeology, Conservation department (2010).

5. Chiara (Bedon) and Massimo (Fragiacomo), "Numerical analysis of timber-to-timber joints and composite beams with inclined self-tapping screws", Composite Structures, Vol. 207, (2019) 13-28 (https://doi.org/10.1016/ j.compstruct.2018.09.008).

6. CSI (Computers and Structures Inc.), Analysis Reference Manual for SAP2000 ver.19: Linear and Nonlinear Structural Analysis Software, CSI, Berkeley, CA, USA, 2017.

7. Daňková (Jana), Mec (Panvel) and Šafrata (Jiri), "Experimental investigation and performance of timber-concrete composite floor structure with non-metallic connection system", Engineering Structures, Vol. 193, (2019) 207-218 (https://doi.org/10.1016/j.engstruct.2019.05.004).

8. FPL (Forest Products Laboratory), Wood Handbook, Wood as an Engineering Material, Centennial Edn. FPL, United States Department of Agriculture Forest Service, Madison, WI, USA, 2010, 5-7. (http://www.fpl.fs.fed.us, accessed in 09/05/2017).

9. FSC (Foam Sheathing Coalition), IRC wall bracing: a guide for builders, designers and plan reviewers, Foam Sheathing Coalition, Woodbridge, UK, 2006 (www.foamsheathing.org; accessed 11/07/2019).

10. Gindy (Ramez), "Archaeological and artistic study of timber ceilings during Mamluk era in Cairo through archives' documents and archaeological buildings", Master thesis, Cairo University, Faculty of Archaeology, archaeological Islamic department (2003).

11.Giongo (Ivan), Schiro (Gianni) and Riccadonna (Daniele), "Innovative pre-stressing and cambering of timber-to-timber composite beams", Composite Structures, Vol. 226, Issue 111195, (2019) 37-48 (https://doi.org/10.1016/ j.compstruct.2019.111195).

12.Gubana (Alessandra), "State-of-the-Art Report on high reversible timber to timber strengthening interventions on wooden floors", Construction and Building Materials, Vol. 97 (2015) 25-33 (http://dx.doi.org/10.1016/ j.conbuildmat.2015.06.035).

13. Hajianmaleki (Mehdi) and Qatu (Mohammad), Mechanics of composite beams, advances in composite materials - analysis of natural and man-made materials, Dr. Pavla Tesinova (Ed.), InTech, Croatia, 2011 (http://www.intechopen.com/books/advances-incomposite-materials-analysis-ofnatural-and-man-made-materials/mechanics-of-compositebeams).

14. Hamed (Safaa), "Study of changes in dissection composition for some species of archaeological woods under different deterioration causes and its appropriate conservation 
techniques, with application on some selected monuments", Ph.D. thesis, Cairo University, Faculty of Archaeology, Conservation department (2009).

15.Hibbeler (Russell), Structural Analysis, $9^{\text {th }}$ Edition, Pearson Publication, US, 2014, pp. $83-124$.

16.Johnson (Robert), Composite Structure of Steel and Concrete, Vol. 1 (Second Edition), Blackwell, Scientific Publication, U.K., 1994, pp. 42-89.

17.Mahir (Mostafa), Hadidi (Nesrin) and Abdel-Aty (Yaser), Study of structural deficiencies and damages in timber roofs at Islamic historic buildings in Cairo, their causes and methodology for restoration and retrofitting: Applying to Ghanim al-Bahlawan mosque in Cairo, the $4^{\text {th }}$ International Conference of Restoration of Minia University, Faculty of Fine Arts, Minia Governorate, Egypt, (2015) 37-43.

18.MHUUC (Ministry of Housing, Utilities \& Urban Communities), Egyptian code of practice for calculating loads in structural and masonry work (ECP 201-2008), Cairo, Egypt, 2008 (in Arabic).

19.MHUUC (Ministry of Housing, Utilities \& Urban Communities), Egyptian code of practice for design and execution of masonry buildings (ECP 204-2005), Cairo, Egypt, 2005 (in Arabic).

20.Monetto (Ilaria) and Campi (Francesca), "Numerical analysis of two-layer beams with interlayer slip and step-wise linear interface law", Engineering Structures, Vol. 144, (2017) 201-209 (http://dx.doi.org/10.1016/j.engstruct.2017.04.010).

21.O'Loinsigh, C., Oudjene, M., Ait-Aider, H., Fanning, P., Pizzi, A., Shotton, E. and Meghlat, E., "Experimental study of timber-to-timber composite beam using weldedthrough wood dowels", Construction and Building Materials, Vol. 36, (2012) 245-250 (http://dx.doi.org/10.1016/ j.conbuildmat.2012.04.118).

22.Ramadan (Zeinab), "Timber ceilings during Ottoman era", Master thesis, Cairo University, Faculty of Archaeology, archaeological Islamic department (1992).

23. Sousa (João) and Silva (Amilton), "Analytical and numerical analysis of multilayered beams with interlayer slip", Engineering Structures, Vol. 32, (2010) 1671-1680 (http://dx.doi.org/10.1016/j.engstruct.2010.02.015).

24.UNI (Ente Nazionale Italiano di Unificazione), UNI 11119:2004: Beni culturali Manufatti lignei, strutture portanti degli edifice - Ispezioni in situ per la diagnosi degli elementi in opera, UNI, Milan, Italy, 2004 (in Italian).

25.Wen (Jie), Sheikh (Abdul-Hamid), Uddin (Alhaz) and Uy (Brian), "Analytical model for flexural response of two-layered composite beams with interfacial shear slip using a higher order beam theory", Composite Structures, Vol. 184, (2018) 789-799. 